\title{
Geological interpretation of current subsidence and uplift in the London area, UK, as shown by high precision satellite-based surveying
}

\author{
Don Aldiss $^{{ }^{*}}$, Helen Burke ${ }^{1}$, Barrie Chacksfield ${ }^{1}$, Richard Bingley ${ }^{2}$, Norman Teferle ${ }^{2,5}$, \\ Simon Williams ${ }^{3}$, David Blackman ${ }^{3}$, Richard Burren ${ }^{4}$ and Nigel Press ${ }^{4}$ \\ ${ }^{1}$ British Geological Survey (BGS), Keyworth, Nottingham, UK. \\ ${ }^{2}$ Institute of Engineering Surveying and Space Geodesy (IESSG), now Nottingham \\ Geospatial Institute (NGI), University of Nottingham, UK. \\ ${ }^{3}$ Proudman Oceanographic Laboratory (POL), now National Oceanography Centre (NOC), \\ Liverpool, UK. \\ ${ }^{4}$ Nigel Press Associates Ltd (NPA) - now NPA Satellite Mapping, CGG, Crockham Park, \\ Edenbridge, Kent, UK. \\ ${ }^{5}$ Current address: Faculté des Sciences, de la Technologie et de la Communication, \\ University of Luxembourg 6, rue Richard Coudenhove-Kalergi, $\mathrm{L}^{-1} 359$ Luxembourg \\ * Corresponding author (e-mail: dta@bgs.ac.uk)
}

Running title: Current subsidence and uplift in the London area

Keywords: PSI; land level change; Holocene; tectonic control; London

\begin{abstract}
Long term planning for flood risk management in coastal areas requires timely and reliable information on changes in land and sea levels. A high resolution map of current changes in land levels in the London and Thames estuary area has been generated by satellite-based persistent scatterer interferometry (PSI), aligned to absolute gravity (AG) and global positioning system (GPS) measurements. This map has been qualitatively validated by geological interpretation, which demonstrates a variety of controlling influences on the rates of land level change, ranging from near-surface to deep-seated mechanisms and from less than a decade to more than 100,000 years' duration.

During the period 1997 to 2005, most of the region around the Thames estuary subsided between 0.9 and $1.5 \mathrm{~mm} \mathrm{a}^{-1}$ on average, with subsidence of thick Holocene deposits being as fast as $2.1 \mathrm{~mm} \mathrm{a}^{-1}$. By contrast, parts of west and north London on the Midlands Microcraton subsided by less than $0.7 \mathrm{~mm} \mathrm{a}^{-1}$, and in places appear to have risen by about $0.3 \mathrm{~mm} \mathrm{a}^{-1}$. These rates of subsidence are close to values determined previously by studies of Quaternary sequences, but the combined GPS, AG and PSI land level change data demonstrate a new level of local geological control that was not previously resolvable.
\end{abstract}

Abstract word count: 207

Text word count 8269, excluding title, authors, keywords, abstract and references Text word count 10430, whole file including references. 


\section{Introduction}

The general pattern of relative sea-level change around Britain has long been recognised from landforms such as raised beaches in Scotland and Wales, and 'submerged forests' and 'drowned' river valleys in southern England (Shennan, 1989). Typically, these are a consequence of changes in both absolute sea level and absolute land level, relative to the geoid. Latterly, it has been possible to estimate rates of land level change during the late Quaternary. Broadly speaking, such estimates have been based either on mathematical models of crustal behaviour, specifically glacio-isostatic adjustment (GIA), such as those of Peltier et al. (2002) and Bradley et al. (2011), or on the interpretation of radiometrically-dated horizons in late Quaternary coastal sedimentary sequences (Shennan, 1989; Shennan and Horton, 2002; Shennan et al., 2006; Gehrels, 2010).

Comparison of continuous global positioning system (CGPS) measurements of present-day absolute crustal motion with modelled predictions of GIA in the British Isles (comprising the UK and Ireland) show that the vertical elements of motion are highly correlated, implying that GIA (here related principally to the British ice-sheet) is the dominant process controlling absolute uplift and subsidence (Bradley et al., 2009). The GIA model of Bradley et al. (2011) predicts uplift of more than $0.8 \mathrm{~mm} \mathrm{a}^{-1}$ in central Scotland, and subsidence of between 0.6 and $0.8 \mathrm{~mm} \mathrm{a}^{-1}$ in most of southern and eastern England. Other GIA models find a similar pattern of land level change, but with different rates reflecting the different models of past ice distribution and of visco-elastic behaviour in the Earth's crust (Peltier et al., 2002; Bradley et al., 2009, and references therein).

The geologically-based studies show a generally similar pattern of uplift in Scotland and northern England and subsidence in southern Britain, although this variation is relative to sea level. Maximum rates of uplift, of $2.0 \mathrm{~mm} \mathrm{a}^{-1}$, are found in western Scotland, varying to subsidence of as much as $1 \mathrm{~mm} \mathrm{a}^{-1}$ in Essex and maximum subsidence of $1.5 \mathrm{~mm} \mathrm{a}^{-1}$ in western Ireland (Shennan and Horton, 2002; Gehrels, 2010). However, such determinations of local sea level change are commonly based on data from several localities at some distance from each other, the rates of change are typically non-linear, and, as pointed out by Gehrels (2010), late Holocene sea level curves for the British Isles are subject to various global, regional and local processes that can influence sea level change. These factors all present difficulties to the interpretation of geologically-based Holocene sea level curves as indicators of land level change at the present day.

These two methodologically independent approaches to this topic provide comparable results: they are, within their limitations, robust and successful (Bradley et al., 2011). However, neither method provides a level of detail that is sufficient to demonstrate (A) the actual rate of absolute or relative land level change at the present time, or (B) how changes in land level might vary through the region, both of which are required for assessments for the long term planning of flood risk management, as along the Thames estuary. For example, local geological controls on spatial variation in the rates of present-day land level change have been found in the Venice area of north-east Italy (Tosi et al., 2009), and in the Segura River Basin of south-east Spain (Tomas et al., 2011).

A study to determine rates of change in land level and in relative sea level around the UK was undertaken from March 1997 to December 2005 (Bingley et al., 2007; Bingley et al., 2008). This project determined the average 'background' rate of sea-level change in British coastal waters, decoupled from changes in land level, i.e. the component of sea level change that 
includes the consequences of global climate change, which was found to be a rise of about $1 \mathrm{~mm} \mathrm{a}^{-1}$. The project also determined the absolute rate of land level change in the London and Thames estuary area. The relative rate of sea level change in the Thames estuary at the present time can thereby be separated into its two components. Relative rates of ground motion (as determined from geological observations) can be approximately compared with absolute rates of ground motion (determined by modelling or by instrumental observation) by allowing for this absolute rate of sea level change, although that rate will have changed through time.

On a national scale, the project involved the serial measurement of land levels by absolute gravity (AG) (Williams et al., 2001) and global positioning system (GPS) methods. For this project, requiring the measurement of millimetric changes in land level, two different approaches to the GPS data processing were used (Bingley et al., 2007; Teferle et al., 2009). On a regional scale, the project also used serial measurements from GPS, but in addition it included the determination of ground velocity for about 950,000 points using PSI (persistent scatterer interferometry) techniques. The PSI data were corrected using the AG/GPS determinations to provide a measure of absolute ground motion, relative to the geoid (Bingley et al., 2008).

This paper presents a geological interpretation of the AG/GPS-aligned PSI land level change data, demonstrating (A) that the PSI data is non-random, and so is a valuable tool for assessing patterns of modern ground movement, especially when aligned with measures of absolute ground movement, (B) local and regional patterns of ground movement and (C) probable mechanisms controlling those movement patterns.

\section{Geological setting of London and the Thames estuary area}

The geological setting of the London and Thames estuary area is described by Sumbler (1996) and Ellison et al. (2004). It is dominated by the synformal London Basin, which is bounded to the north-west and to the south by the Chalk Group and by older Cretaceous formations (Fig. 1). The main part of the London Basin is underlain by Palaeogene deposits, of which by far the most extensive is the London Clay Formation. That is underlain in turn by the Lambeth Group, also mostly composed of clay although with some sands and gravels, and by the Thanet Sand Formation, which is dominantly composed of silts and fine-grained sands. The London Clay is locally overlain by sands of the Bracklesham Group, here represented by the Bagshot Formation.

These bedrock formations are extensively covered by a variety of superficial deposits of Quaternary age. On the higher parts of the Chiltern Hills and the North Downs, the Chalk is partly overlain by the clay-with-flints, a clay-rich remanié deposit largely derived from a previous cover of Palaeogene sediments. The southern limit of the Anglian ice sheet lies within the north of London, and much of the northern part of the study area is underlain by clay-rich till, with some glaciofluvial deposits. River terrace deposits are, however, the most widespread type of superficial deposit, forming discontinuous flights at various levels. The youngest terrace deposits, dating from the late Devensian, are partly covered by Holocene alluvial sediments laid down on the flood plains of the River Thames and its tributaries (Ellison et al., 2004).

The natural land surface has been anthropogenically modified in various ways. Made ground is widespread, both in engineered embankments for transport routes, flood defence and so 
forth, and also as broad spreads within well-established urban areas. Much of central London, for example, is underlain by several metres of made ground. Mineral workings are fairly common, and in some cases have been infilled by waste. There are extensive areas of reclaimed land on either side of the Thames estuary, and in some cases the ground surface there has been artificially raised for development.

No seismic surveys of the geological basement in the London area are available, so its structure is revealed only by the regional geophysical fields, corroborated by the few boreholes that penetrate the base of the Cretaceous strata in this region (Ellison et al., 2004, fig. 2). Variations in the regional Bouguer gravity anomaly field in the London area largely relate to geological formations occurring beneath the Chalk Group, mostly of Palaeozoic or Proterozoic age. The gravity data were processed using standard techniques, such as gravity stripping, to enhance these variations (Aldiss et al., 2006). The resulting map shows portions of three geological terranes within the pre-Mesozoic basement underlying the study area (Fig. 2). (The regional magnetic map was also considered but was found to provide little additional useful information, in part because of incomplete coverage, and electrical interference from anthropogenic sources.)

The north-western part of the study area is underlain by the Midlands Microcraton, where Proterozoic rocks occur at relatively shallow depths, and which has been relatively tectonically stable during the Phanerozoic. Structural trends are complex. The north-eastern part of the area is underlain by a portion of a Caledonide fold belt, formed during midPalaeozoic times, in which the dominant structural trends are north-west to south-east. The southern part of the area includes the northern margin of a Variscan fold belt, formed in late Palaeozoic times. This terrane is represented by arcuate structural trends, oriented approximately east-west (Lee et al., 1993). The Variscan fold belt was the site of basin subsidence during the Mesozoic and basin inversion during the Cenozoic, whereas the Midlands Microcraton and the Caledonide foldbelt (together forming the London Platform) remained relatively stable during that time. Note that the exact position of the northern margin of the Variscan fold belt, the Variscan Front, is uncertain, although the location shown in Fig. 2 has been shown to be plausible by Busby and Smith (2001). Ellison et al. (2004) ascribe the area of the large gravity 'low' in the south of the study area (Fig. 2) to 'a zone of transition between the London Platform and the Variscan fold belt'. This gravity low is taken to mark a very thick sequence of post-Caledonide strata, probably of Devonian age. It is separated from the Midlands Microcraton by a zone of north-east to south-west trending basin margin faults, as indicated by linear features in the gravity field (Fig. 2). This basin margin fault zone is likely to be quite complex at depth, becoming simpler upwards. Faults and folds seen in the bedrock under south-west London, including the Wimbledon and Greenwich faults and subparallel fault zones discussed elsewhere in this paper, formed by later movement in this structural zone.

The geological processes operating in and around the region that might influence current changes in land level were reviewed by Muir Wood (1990) and Bingley et al. (1999). These processes are expected to include glacio-isostatic adjustment (GIA), tectonic processes, changing groundwater levels, natural compaction (especially of alluvial deposits), anthropogenic compaction due to loading, and movement of ground due to shrink-swell behaviour where Palaeogene-aged clays are at or close to the surface.

\section{Determinations of changes in land level and vertical ground velocity}


PSI is based on the analysis of synthetic aperture radar (SAR) reflections detected during multiple successive passes of a survey satellite. The corresponding phase measurements from two consecutive SAR images are used to create an interferogram, which can be related to the change in radar signal path length. Knowing the precise position of the satellite, this change can in turn be related to movements of the ground surface using Differential SAR Interferometry (DInSAR). PSI is a DInSAR technique that considers the phase differences in a series of SAR images for a specific area and selects pixels based on their phase stability through time: these pixels are referred to as 'Persistent Scatterer' (PS) points (Ferretti et al., 2000). PS points correspond to stable, radar-reflective objects such as built structures or bare rock. In some cases, a specific reflector can be identified; but in most, not with certainty (Riedmann and Haynes, 2007). The time series of measurements for each PS point over a period of some years is used to create a scatter graph of changing land level. A linear regression of this graph yields an average velocity for that point. A example of such a time series graph from the present study is shown as Figure 6.1 by Bingley et al. (2007), who note (p. 108) that 93\% of these determinations of line-of-sight velocity have an uncertainty of $\pm 0.25 \mathrm{~mm} \mathrm{a}^{-1}$ or less. An example from other work is shown by Riedmann and Haynes (2007).

The PSI technique, and its use to overcome some of the drawbacks of other kinds of DInSAR technique, and its accuracy in detecting sub-millimetric ground deformation, is described by (Ferretti et al., 2000, 2001), Colesanti et al. (2003a), (Colesanti et al., 2003b) and Crosetto et al. (2010). Adam et al. (2009) discusses the validation of PSI data used by the Terrafirma project, a European Space Agency (ESA) project to provide a pan-European ground motion hazard information service.

For the study of the London and Thames estuary area, the area of interest was approximately $95 \times 55 \mathrm{~km}$ in extent, aligned with the satellite track, centred just east of London (Fig. 1). This area encompassed a network of three CGPS (continuously-measured GPS) and 12 EGPS (episodically-measured GPS) stations, established in 1997. A total of 60 descending ERS and ENVISAT SAR scenes (Track 51, Frame 2565) spanning nearly nine years (March 1997 to December 2005) were processed by Nigel Press Associates Ltd., to generate a dataset of about 950,000 PS points (Bingley et al., 2007; Bingley et al., 2008).

\subsection{AG, GPS and PSI combination}

The advantage of PSI, compared with GPS, is that it provides excellent spatial coverage with a sufficient density of determinations to demonstrate local variation and to be analysed statistically. Also, the potential time span of the datasets is generally longer than for the GPS network, depending on the availability of suitable images in the ESA archives.

The major restriction of the PSI technique is that the determinations of ground velocity are relative to the master scene and a ground control point, whereas the GPS and AG techniques independently provide measurements in an absolute terrestrial frame of reference. Also, PSI measures the change in distance along the satellite 'line-of-sight': an additional processing step has to be applied to isolate the vector of vertical movement, or vertical ground velocity.

To overcome these restrictions, in this study the PSI determinations of ground velocity were aligned with the terrestrial frame of reference established by AG and GPS methods. The PS points within $300 \mathrm{~m}$ of each of the GPS stations were examined, bearing in mind the likely corresponding reflector and its relationship to the underlying geology - and so the possibility 
of differential movement between nearby PS points. This exercise enabled the calculation of a 'shift' factor of $-0.66 \mathrm{~mm} \mathrm{a}^{-1}$ to convert the line-of-sight velocity given for the PS points with respect to the reference scatterer, to AG/GPS-aligned PSI estimates of vertical ground velocity. This 'shift' was applied to each of the 950,000 PS points individually (Bingley et al., 2007; Bingley et al., 2008).

\section{The need for geological interpretation}

The expected medium to long term changes in land level are very small (in the orders of 0.1 to $10 \mathrm{~mm} \mathrm{a}^{-1}$ ) compared with short term changes such as earth body tides (typically several 10s of cm daily variation) (House, 1995; Wahr, 1995), ocean tide loading (up to about $10 \mathrm{~cm}$ daily variation) (Baker et al., 1995) and ground movements due to shrinking and swelling of clay soils (up to about $5 \mathrm{~cm}$ seasonal variation) (Boyle et al., 2000; Teeuw, 2007). Along with variations and uncertainties within the data collection and processing systems (Riedmann and Haynes, 2007; Ferretti et al., 2001), it seemed possible, a priori, that the signal-to-noise ratio in the PSI dataset would be too small to be useful - or that the data processing might induce a spurious pattern of variation.

It was therefore important to subject the AG/GPS-aligned PSI estimates of vertical ground velocity (referred to simply as 'land level change data' hereafter) to geological interpretation. If it could be shown that variation in these land level change data can be correlated with geological phenomena, then this would demonstrate that the data (or at least some aspects of it) are 'real': the geological interpretation would be a means of independently validating the measurements in qualitative terms. The comparison of these data with the local geology would also serve to identify the vertical ground velocity characteristics of flood-prone areas: whether these are moving at the regional average rate, or not; and whether all flood-prone areas are moving at the same rate. Other PSI studies have been validated by use of multiple datasets or by comparison with GPS or ground-based levelling surveys (for example, Heleno et al., 2011) but these methods were not generally available during the present study.

The geological interpretation was also intended to identify the controlling mechanisms of vertical ground velocity variation, as a means of assessing likely future changes in land level. In doing so, it would then be possible to assess whether the rates of change determined for the duration of the project represent short-term or long-term trends. These aspects are relevant to planning for flood risk management. They also provide a further independent means of corroborating regional rates of ground movement determined by other methods.

\section{Identification of ‘domains’ of approximately uniform land level change}

Following alignment to the AG/GPS frame of reference, the values of vertical ground velocity determined for the 950,000 PS points ranged from -22.3 to $+11.9 \mathrm{~mm} \mathrm{a}^{-1}$, where negative values indicate subsidence and positive values indicate uplift (Table 1 and Fig. 3). About $83 \%$ of all the PS points have a negative value, with $63 \%$ between 0 and $-1.5 \mathrm{~mm} \mathrm{a}^{-1}$. The average change in land level for the area of interest was $-0.80 \mathrm{~mm} \mathrm{a}^{-1}$, with a standard deviation of $0.89 \mathrm{~mm} \mathrm{a}^{-1}$, implying that $95 \%$ of the values lie between -2.56 and $+0.98 \mathrm{~mm} \mathrm{a}$ ${ }^{1}$. The rates of subsidence found by AG/GPS-aligned PSI are broadly consistent with terrestrial geodetic levelling that found that some sites in central London subsided by as much as $2 \mathrm{~mm} \mathrm{a}^{-1}$, relative to sea level, between 1932 and 1962, and that the difference in height between Sheerness and central London (Fig. 1) increased by $70 \mathrm{~mm}$ between 1829 and 1953, an average rate of change of about $0.6 \mathrm{~mm} \mathrm{a}^{-1}$ (Kelsey, 1972). 
In order to better display the variations in the data, as shown in a map in which the individual data points have been plotted (Fig. 3), they were classified by intervals of $0.5 \mathrm{~mm} \mathrm{a}^{-1}$ between +2 and $-2 \mathrm{~mm} \mathrm{a}^{-1}$, and by intervals of $1 \mathrm{~mm} \mathrm{a}^{-1}$ from +2 to +3 and from -2 to $-3 \mathrm{~mm} \mathrm{a}^{-1}$. Values between -3 and -22 and between +3 and $+12 \mathrm{~mm} \mathrm{a}^{-1}$ were each classified as a single category, in order to suppress the graphical effects of outlying values, which tended to obscure the variations represented within the bulk of the data: only $1.6 \%$ of the data lies in these two extreme categories. Considering the observational and methodological uncertainties in the GPS, AG and PSI data, and the apparent noise level in the data itself, we feel that it is not possible to draw firm conclusions regarding changes in land level of less than about $0.5 \mathrm{~mm} \mathrm{a}^{-1}$ magnitude. Although this estimate is not based on a systematic calculation of uncertainty, it is justified by the observations reported in this paper, which show clear spatial correlations between the larger variations in the PSI data and the various geological datasets, whereas the smaller variations are not obviously so correlated. However, it may be that some of the smaller variations in the PSI data, not interpreted for this study, are nevertheless significant.

It is clear from the data point plot (Fig. 3) that the average changes in land level are far from being evenly distributed, with one area having mainly undergone uplift, some areas having mainly undergone subsidence and some areas where there are roughly equal numbers of PS points indicating either uplift or subsidence. However, there is also some apparently random scatter throughout: for example, even the areas that are dominated by PS points with higher rates of negative vertical ground velocity have some PS points with very low negative vertical ground velocity, or with positive vertical ground velocity (net uplift).

For this study it was not meaningful (or feasible) to analyse the geological setting of all 950,000 PS points individually. In order to simplify the process of interpretation and also to help ensure that the data could be compared with the geological datasets in a reasonably consistent manner, a variety of data plots were inspected visually to identify 'domains' of approximately uniform characteristics of vertical ground velocity, and to note lineaments within the data distribution (Fig. 3B). This is analogous to procedures used for the geological interpretation of more conventional types of satellite image, and of aerial photographs (Drury, 1993), in which observed heterogeneities within the image are interpreted in terms of geological structures or processes.

To facilitate the identification of the domains, the data were plotted in several different ways, for example as point plots using only subsets excluding the median values, or using different colour ramps, or as inverse distance weighted (IDW) grids. Although these different plots tended to enhance different aspects of the distribution of vertical ground velocity, a consistent pattern emerged. It should be emphasised that this delineation of the domains and identification of the lineaments was, except very locally, undertaken without reference to the geoscience datasets with which they were subsequently compared. In a very few places, the domain boundaries were subsequently modified when considering some specific features at larger scales, but this was not done systematically.

The domains were ranked from 1 to 6 on the basis of their visual appearance, with individual areas within each rank given suffix letters to assist reference (Fig. 4). Domains with the same rank represent similar vertical ground velocity data populations. This qualitative visual analysis was substantiated by computing the average value for the PS points within each domain, which showed that the variance and standard deviation of the populations within 
each domain ranked 1 to 5 are reasonably uniform (Fig. 4; Table 1). The domains ranked 6 are generally smaller and have greater variance.

From these data, it appears that the domains ranked 4, 5 and 6 have experienced subsidence, in general. Domains ranked 2 and 3 have, on the whole, also undergone subsidence, but these domains are of intermediate and mixed character, with some parts having undergone subsidence and some uplift. The average vertical ground velocity in Domain 1 is $0.34 \mathrm{~mm} \mathrm{a}^{-1}$ (Fig. 4 and Table 1) and so it appears to have undergone slight uplift overall. However, the present authors do not feel confident in assigning meaning to differences in vertical ground velocity of less than about $0.5 \mathrm{~mm} \mathrm{a}^{-1}$. On this basis, it is therefore possible that, rather than uplifting, Domain 1 is actually stable or is very slowly subsiding overall.

\section{Geological analysis and interpretation}

The geological analysis was carried out by systematically comparing the vertical ground velocity domains inferred from the land level change data with a number of geological datasets, at various scales, in a geographic information system (GIS). Comparisons were made by visual inspection of an on-screen display.

In the main, point plots were used for the geological interpretation rather than gridded representations of the data. Although grids give a similar appearance to point plots when viewed at small scales (the effective scale of the whole dataset on a 19-inch computer screen is about 1:420,000), investigation of local detail at larger scales is not feasible with the gridded data due to the pixelation of the image. Also, in areas of low data density the apparent extent of extreme values tends to become exaggerated in grids. Conversely, in areas with a dense distribution of PS points, it was found that point plots could be usefully examined at scales as large as 1:20,000.

\subsection{Geological maps}

DiGMapGB-50, a digital representation of the 1:50,000 scale geological maps produced by the British Geological Survey, was used to examine correlations with near-surface geology. The geological information has been separated into themes that can be viewed individually or in combination within a GIS: pre-Quaternary formations (bedrock) cropping-out at rockhead; line symbols (including fault lines); superficial deposits (of Quaternary age); and artificially modified ground (chiefly made ground, such as embankments or landfill, and worked ground, such as engineered cuttings and quarries).

Much of the London area is underlain by Palaeogene clays of the London Clay Formation and the Lambeth Group (Fig. 1), which typically are particularly susceptible to changes in volume with changing moisture content. This shrink-swell behaviour can give rise to vertical ground movements of up to $50 \mathrm{~mm}$ or more over quite wide areas (Boyle et al., 2000; Teeuw, 2007), but the movement is reversible and can be observed to follow seasonal variation in precipitation (Bingley et al., 1999; Boyle et al., 2000). The current project combined ground movement data from seasonal cycles over nine years. No clear correlation of the land level change data with clay formations - or with any other aspect of the bedrock geology map could be found. Nevertheless, it seems probable that much of the local variation (or 'noise') in the land level change data is caused by variations in ground movement on clay soils, reflecting the very complex distribution of factors that influence soil moisture content, such 
as surface sealing, proximity to trees, and leaking service pipes, as well as compositional variation in the clay-rich formations.

Linear discontinuities, trending north-east to south-west, are apparent in the distribution of average vertical ground velocity values (Figs. 3 and 4). The relative abruptness of the change in average vertical ground velocity apparent at these lineaments suggests that they mark fault zones at a relatively shallow level, probably at rockhead. More diffuse changes would be expected to mark linear structures at deeper levels. Indeed, this may be the case in the north of the area, where the lineaments across London become less well-defined.

These lineaments are sub-parallel to the en echelon swarm of faults that has been mapped in south-west London: principally the Wimbledon, Streatham and Greenwich faults (Ellison et al., 2004) (Fig. 5). Part of one extensive lineament is coincident with part of the Wimbledon Fault, which is downthrown on its south-east side. The width of the Thames floodplain increases markedly downstream of the same lineament, where it crosses the River Thames, as shown by the outcrop of the Holocene deposits (Fig. 5). This implies a sense of 'down to the south-east' motion, but that is contrary to the throw of the nearby Greenwich Fault, suggesting that additional sub-parallel faulting occurs north-west and north of the Greenwich Fault. An example of such faulting, forming the Plaistow Graben, was discovered during work for the Lea Valley tunnel and other major civil engineering projects (Mortimore et al., 2011, fig.14). These correlations imply that some of the differential ground movement revealed by the land level change data has been accommodated by movement on near-surface tectonic structures, some of which (as noted below) extend from the tectonic basement.

The only correlation of the land level change data with the distribution of superficial deposits was found in Domains 5F, 6D, 5C and 6E, which coincide with extensive areas of alluvial or estuarine deposits adjacent to the rivers Lea, Thames and Medway (Fig. 5). These Holocene deposits are compressible, and are susceptible to subsidence due either to autocompaction or to imposed loading (Paul and Barras, 1998). Holocene deposits can also undergo significant shrinkage through desiccation of the topmost few metres of sediment. This can occur in areas where Holocene deposits have been protected from flood (Allen, 2000a). Where Holocene deposits are most extensive and generally thick (typically between about $5 \mathrm{~m}$ and $20 \mathrm{~m}$ ), there is a clear correlation with the areas found to be most prone to subsidence. Analogous results have been found in other studies, for example by Tomas et al. (2011). The rates of subsidence in these domains are between 0.4 and $1.1 \mathrm{~mm} \mathrm{a}^{-1}$ greater than on adjacent ground outside the Holocene outcrop (Fig. 4 and Table 1), differences that are comparable with compaction rates in Holocene sediments found elsewhere in England (Horton and Shennan, 2009).

In the upper parts of the river catchments, including the River Thames upstream of Domain $6 \mathrm{D}$, where alluvium is less extensive and can be expected to be less than $5 \mathrm{~m}$ thick, in general, the Holocene deposits show essentially the same range and distribution of average velocity values as in the adjacent ground. Note that Domains 5A, 5B, 6A, 6B and 6C (Figs. 4 and 5) do not coincide with occurrences of Holocene deposits.

However, there are some anomalous areas of relatively slight subsidence (or apparent average uplift of up to about $1 \mathrm{~mm} \mathrm{a}^{-1}$ ) that are within the Thames Holocene outcrop immediately adjacent to Domain 6D, and so which would be expected to have a similar average vertical ground velocity of about $-2.0 \mathrm{~mm} \mathrm{a}^{-1}$. These areas occur where there is extensive building on made ground. The most notable coincide with the Dagenham motor works, mill buildings at Purfleet, and the Canning Town and Stratford areas near the mouth of the Lea Valley (Fig. 5). 
In general, these anomalous areas are now experiencing the same rate of ground movement as found in adjacent ground outside the alluvium. The most likely explanation of this phenomenon seems to be that the anomalous areas have been built on for relatively long periods (the main motor works at Dagenham was developed prior to 1938, for example), and so that the alluvium (and overlying made ground) has reached its effective limit of compaction. Similarly, Tomas et al. (2011) found a lower rate of subsidence inside the ancient city centre of Murcia, Spain, compared with that in the surrounding urban area.

Some small domains of rapid subsidence can be correlated with underground engineering works, rather than artificially modified ground or alluvium at the surface. For example, a linear zone of subsidence (Domain 6C), previously identified by Nigel Press Associates Ltd., coincides with part of the route of the Jubilee Line Extension underground railway, which was built between 1995 and 1999 (Figs. 4 and 5) (Burland et al., 2001; Standing and Burland, 2006; Teeuw, 2007, fig.5).

Long-term differential ground movement between Domain 1 and parts of domains 2A and 3B appear to be indicated by an anomaly in the path of the River Thames, and in the distribution of associated deposits. The River Thames flows generally eastwards from Bray to the North Sea across the Palaeogene outcrop in the London Basin, albeit on a meandering path (Figs. 1 and 6). Between Windsor and Chiswick, however, its course traces a broad loop that extends as much as $10 \mathrm{~km}$ south of the most direct line. There is no obvious feature in the nearsurface bedrock that accounts for this southwards loop. The area within this loop is underlain by broad outcrops of the Taplow Gravel and the Kempton Park Gravel, which form two of the youngest river terrace deposits of the Thames, that are mostly on the north bank. This relationship suggests that the difference in rates of ground movement between Domain 1 and the area to the south has persisted during deposition of these river terraces, so creating a local differential ground motion across which the River Thames has gradually been diverted southwards. The older, Taplow Gravel dates from more than about 150,000 years ago (Ellison et al., 2004). In addition, the downstream limit of the Shepperton Gravel outcrop, which is the youngest terrace deposit, occurs within this southwards-deflected section of the River Thames. This is close to the boundary between Domains 2A and 3B, which marks a differential ground movement of about $0.5 \mathrm{~mm} \mathrm{a}^{-1}$ (Figs. 4 and 6). To the east, where the ground is subsiding faster, on average, the Shepperton Gravel is entirely sub-alluvial.

\subsection{Groundwater level}

Changes in groundwater level can be reflected in changes in local ground level. When water is extracted from the ground (for public water supply, for example), the ground surface tends to subside as the water table falls. If the water table recovers, then some uplift of the ground surface can be expected, but only by up to about 10 per cent of the subsidence (Freeze and Cherry, 1979). Since 1991, the Environment Agency has published an annual report on the position of the water table in the main aquifer under London, within the Late Cretaceous Chalk Group and early Palaeogene Thanet Sand and Upnor formations. The change in groundwater level during approximately the same period as represented by the land level change data (March 1997 to December 2005) was derived from maps of the water table in January 1997 and January 2006 (Environment Agency, 1997, 2006) (Fig. 7).

The most striking correlation with the land level change occurs in the Merton area of southeast London, where groundwater levels were lowered by at least $30 \mathrm{~m}$ as a consequence of abstraction at public water supply boreholes. The largest drawdown in the water table is 
centred close to the Merton Abbey public water supply well, one of a number of sites in this part of the London area where water is abstracted from the Chalk at depths in excess of $70 \mathrm{~m}$. Coincidentally, the Merton Abbey well had not been used since 1987 until pumping resumed in 1995 (Environment Agency, 1997).

The area of depressed groundwater level around Merton coincides with an area of relatively greater subsidence (Domain 5A in Figs. 4, 5 and 7). No other explanation for the existence of this domain has been identified, so it appears that groundwater abstraction has caused this domain to subside some $0.5 \mathrm{~mm} \mathrm{a}^{-1}$ faster than the surrounding area (Fig. 4 and Table 1). This differential rate of subsidence is consistent with the shrinkage of the bedrock formations following the recorded local depression of the water table, as predicted by mathematical modelling (Bateson et al., 2009). The north-west edge of Domain 5A is coincident with the Wimbledon Fault (Fig. 6). The north-west edge of the area of lowered groundwater is aligned with the same structure, and with the lineaments in the land level change data (Fig. 7), although the low resolution of the groundwater level data does not necessarily reveal the true extent of the cone of depression. Nevertheless, it appears that fractures parallel to the Wimbledon Fault are exerting some control on groundwater movement (compare Donnelly, 2009). PSI has been used to demonstrate subsidence related to groundwater abstraction in numerous other cities (Heleno et al., 2011; Tomas et al., 2011, and references therein).

Large-scale dewatering of the Thanet Sand Formation associated with the construction of the Channel Tunnel Rail Link (CTRL) took place between Stratford and East Ham during 20012004 (Woods, 2004). The net groundwater lowering of between -5 and $-10 \mathrm{~m}$ in this area (Fig. 7) is partly associated with this operation and partly with groundwater abstraction for public water supply at East Ham (Hamilton et al., 2008; Jones et al., 2012). Domain 5B, in which the rate of subsidence is somewhat greater than in adjacent parts of Domain 4F (which has similar geology), appears to coincide with the south-eastern part of this zone of groundwater depression. The north-westerly extent of Domain 5B is close to a major lineament in average vertical ground velocity distribution, and so is likely to have been controlled by faults such as those forming the Plaistow Graben (Fig. 6), in an analogous manner to that found in Domain 5A.

\subsection{Basement structures}

It is apparent from the foregoing that the smaller domains, which are ranked 5 and 6 (Fig. 4), are controlled by processes acting locally at relatively shallow levels (within $100 \mathrm{~m}$ of the surface). If these domains are disregarded, then a more generalised pattern can be discerned, which is taken to approximate to the 'regional pattern' of average vertical ground velocity, delineated by 'generalised domains' G1 to G5 (compare Figs. 2 and 4). Domain G1 appears to be near-stable or is undergoing slight uplift, on the whole, whereas domains G4 and G5 are subsiding. Ignoring local perturbations caused by near-surface processes, domains G2 and G3 could be experiencing slight subsidence, or neither subsidence nor uplift. This generalised pattern bears little apparent relation to 'near-surface' geology (Figs. 1 and 6) but can be correlated with elements of the deeper geological structure.

The generalised vertical ground velocity domains G1 and, to a lesser extent, G2 coincide with a gravity high within the Midlands Microcraton, in the west of the area (Fig. 2). The southeast margin of Domains G2 and G3 lie parallel to major lineaments in the land level change data, to the Wimbledon Fault, and to the faulted south-east margin of the Midlands Microcraton (Figs. 2 and 5). This correlation implies that in the London area, current stability 
or uplift is confined within the Midlands Microcraton, with the extent of differential movement between G3 and G4 (of about $0.5 \mathrm{~mm} \mathrm{a}^{-1}$ ), being controlled by deep-seated tectonic structures. This differential movement is shown to be a long-term trend by the change in width of the Holocene outcrop alongside the River Thames (noted above) as it passes across the PSI data lineament close to the edge of the Midlands Microcraton (Fig. 5). The northern part of the boundary between domains G3 and G4 has a northerly alignment, turning to lie approximately parallel to the margin of the Caledonide fold belt (Fig. 2).

This interpretation is consistent with findings from a high resolution study of present-day land level change in the Venice coastal plain, north-eastern Italy, also based in part on PSI data. This study found significant spatial variability in land-level change, ranging from uplift of as much as $2 \mathrm{~mm} \mathrm{a}^{-1}$ to subsidence of more than $10 \mathrm{~mm} \mathrm{a}^{-1}$. The sources of this local variability are thought to include structures in the pre-Quaternary basement at depths of more than 400 m below sea level (Tosi et al., 2009).

The cause of the stability (or uplift, if it is real) in Domain G1 and perhaps in G2 is not certain, especially as GIA modelling (Bradley et al., 2011) and geological observations (Shennan and Horton, 2002; Gehrels, 2010) both predict regional subsidence in south-east England. The coincidence of G1 with the centre of the gravity high implies a causative relationship. The gravity high indicates the presence of relatively dense rocks, relatively close to the surface. These are likely to be of Early Palaeozoic or Proterozoic age, forming a structural ridge between Late Palaeozoic basins to the north-east and south-west (Fig. 2). The presence of this ridge implies a zone of relative tectonic stability, apparently enhanced at its south-eastern end by interaction with the faulted margin with the Devonian basin under south London. Occurrence of uplift in Domain G1 would suggest that the tectonic structures that formed the ridge are undergoing rejuvenated movement at the present time.

The south-eastern edge of generalised domain G4 is marked by a topographic lineament aligned with the Medway valley through the Chalk outcrop of the North Downs, and with part of the Essex coastline (Figs. 1, 2 and 5). It approximately follows the margin of the large gravity low in the south of the study area, and other inflections in the gravity field, and so is presumed to mark a basement fault zone subparallel to that forming the south-east edge of the Midlands Microcraton (Fig. 2). Geological evidence for differential movement in Essex parallel to this alignment was noted by Greensmith and Tucker (1980) and Bristow (1985), and parallel structures in various parts of the London Basin were inferred by Wooldridge (1923). South of the Thames estuary, the ground to the south-east of this lineament is mostly subsiding by at least $0.5 \mathrm{~mm} \mathrm{a}^{-1}$ faster than that within Domain G4, a similar differential to that seen between Domains G3 and G4. This differential explains the contrast in rates of subsidence determined for the Canvey Island area (Domain 5C) and the Isle of Sheppey area (Domain 6E) (Fig. 4), both extensively underlain by Holocene deposits. The north-eastern edge of Domain G4 follows the Caledonide structural trend (Fig. 2).

The presence, location and extent of faults and folds in the London Basin area is difficult to determine by conventional geological mapping techniques, due to poor exposure, widespread superficial cover and the extensive outcrop of the London Clay, within which faults juxtapose essentially similar strata (Aldiss, in press.). Numerous authors have inferred the presence of unmapped faults or monoclines in parts of the London Basin (Wooldridge and Linton, 1955; Muir Wood, 1990; Ellison et al., 2004), Thames Estuary (Devoy, 1979) and Essex (Greensmith and Tucker, 1980; D'Olier, 1982; Bristow, 1985) from analysis of Palaeogene, Pleistocene or Holocene sequences, terrestrial geodetic surveys, or tide gauge records. To 
these techniques can now be added PSI analysis. The improved resolution of tectonic structures within the London Basin is currently being addressed by 3D geological modelling at the British Geological Survey (Ford et al., 2010).

\section{Ephemeral movements or long term patterns?}

The ground movements discussed here were measured over a nine-year period in the recent past (1997-2005). They are broadly consistent with rates of movement in this area inferred for the late Holocene (Shennan and Horton, 2002; Gehrels, 2010) but for the purposes of long-term flood risk management, and for interpretation of sea level change from some Holocene sequences, it is important to assess the rates of ground movement over decades and centuries. This can be addressed in the land level change data by considering the controlling mechanisms indicated by the geological interpretation.

Where no further natural sedimentation occurs, shrinkage of Holocene deposits due to compaction or desiccation can be expected to be effectively complete within tens to a few thousands of years, probably, depending on the thickness of the deposits and their composition (Paul and Barras, 1998; Allen, 2000b). Formerly protected areas of Holocene deposits that become flooded, for example through managed retreat, can be expected to resume subsidence (or to continue to subside) due to increased loading by water and by newly deposited sediments.

Some of the more striking examples of subsidence demonstrated by the PSI data are over recently-constructed tunnels. Most such subsidence can be expected to occur during or shortly after construction, as indicated by subsidence monitoring studies (Mair et al., 1993; Burland et al., 2001).

The influence of groundwater abstraction can be demonstrated in some parts of London, locally increasing rates of subsidence by as much as $0.5 \mathrm{~mm} \mathrm{a}^{-1}$. Future subsidence rates related to groundwater abstraction should be in proportion to the rates at which the aquifer is drawn down. However, when abstraction rates reach a 'steady state' within the aquifer, with no further drawdown, then subsidence can be expected to cease, possibly with some time lag reflecting the rates of compaction of the materials that have been dewatered (Freeze and Cherry, 1979). Subsidence due to groundwater withdrawal in the central part of the Venice district, for example, was quickly arrested following recovery of groundwater levels (Tosi et al., 2009).

The regional changes in ground level in the Thames estuary area, of uplift, stability or very slow subsidence in the west and greater rates of subsidence towards the east and south-east, are attributed to deep-seated processes. They can be expected to continue at similar rates over thousands of years, assuming similar conditions. Some possible consequences of climate change, such as rising sea level and increasing river volume, would tend to increase the rates of subsidence in the east of the study area, while others, such as increased rates of erosion, might serve to increase rates of uplift in the west of the area.

The general tendency to regional subsidence in south-east England has been attributed to GIA (Gehrels, 2010). However, the observed variation in the regional average vertical ground velocity within the study area (from about $+0.3 \mathrm{~mm} \mathrm{a}^{-1}$ to $-1.5 \mathrm{~mm} \mathrm{a}^{-1}$ over a lateral distance of $50 \mathrm{~km}$ ), with differential movements of more than $0.5 \mathrm{~mm} \mathrm{a}^{-1}$ occurring within a few kilometres across fault zones, demonstrates that isostatic movements are locally modified by 
basement structures. This indicates that the estimation of regional rates of sea level change by interpretation of Holocene sequences at different localities should take account of their position relative to basement structures. Local tectonic control may also influence the uplift rates observed in river terrace sequences.

Prior to our study, the adopted value for changes in land level for the London region was 0.7 to $0.9 \mathrm{~mm} \mathrm{a}^{-1}$ relative subsidence, based on the geological studies of Shennan and Horton (2002). These were modified to 0.9 to $1.0 \mathrm{~mm} \mathrm{a}^{-1}$ by Gehrels (2010). The values presented here, of between 0.9 and $2.1 \mathrm{~mm} \mathrm{a}^{-1}$ absolute subsidence for the land along the Thames Estuary and River Thames (Fig. 4 and Table 1), significantly increase the range and rate of this value. Combining the regional average vertical ground velocity estimates with determinations of rates of sea-level rise shows that there has been a 1.8 to $3.2 \mathrm{~mm} \mathrm{a}^{-1}$ rise in sea level with respect to the land along the Thames Estuary and River Thames over the past few decades / past century (Bingley et al., 2008).

\section{Conclusions}

The geological interpretation of the AG/GPS-aligned PSI data presented here demonstrates that major variations in that data are not random and can be correlated with the operation of several geological processes, acting either locally or on a regional scale. These correlations serve to validate the AG/GPS-aligned PSI data: although the medium- to long-term rates of motion that they indicate are small compared with short-term variations in ground level, and considering the uncertainties in the underlying datasets, they appear to represent real variations.

In the London and Thames estuary area, AG/GPS-aligned PSI estimates of vertical ground velocity show that regional patterns of uplift and subsidence are controlled, to some extent, by deep-seated geological structures. There is also some local control by near-surface structures, such as the Wimbledon Fault. In places, there is a close relationship between subsidence following water abstraction, and lines of faulting.

Where Holocene deposits are extensive and thicker than about $5 \mathrm{~m}$, the ground is generally prone to a greater rate of subsidence than found regionally, at rates of about $-2 \mathrm{~mm} \mathrm{a}^{-1}$. In some areas, however, where thick Holocene deposits are overlain by old made ground, subsidence due to compression currently appears to be negligible and may have ceased. Groundwater abstraction and tunnelling can cause subsidence at a similar rate to that found within areas of Holocene deposits.

Parts of the study area, north-west of the Wimbledon Fault and its lateral extensions, are prone to uplift at about $0.3 \mathrm{~mm} \mathrm{a}^{-1}$ or subsidence of less than about $-0.7 \mathrm{~mm} /$ year. A small area of apparent uplift is centred on a gravity 'high' within the Midlands Microcraton, presumably associated with a tectonically-controlled block of Proterozoic or Early Palaeozoic rocks. The remainder of the study area is prone to subsidence, mostly at average rates between about -0.9 and $-1.5 \mathrm{~mm} \mathrm{a}^{-1}$, with a marked increase to the south-east of a east-northeast-west-south-west geophysical lineament passing through the North Downs along the Medway valley and inferred to mark basement structures. This increase is in addition to the rates of subsidence observed in the Holocene deposits, so that comparable areas of Holocene deposits are, in general, subsiding faster to the east of this 'Medway lineament' than to the west. 
These findings broadly corroborate the determinations by Shennan and Horton (2002) and of Gehrels (2010) for the Thames estuary area, but show a significantly greater range of local variation. Future analysis of Quaternary land level change as shown by the geological record should, where possible, take account of the local tectonic structure and its potential controlling influence. It cannot be assumed that rates of land level change are uniform, or vary uniformly, over large areas of the United Kingdom.

None of these findings would have been possible without the satellite-based surveying technique of PSI. They were part of a project whose main conclusion on a regional scale is that there has been a 1.8 to $3.2 \mathrm{~mm} \mathrm{a}^{-1}$ rise in sea level with respect to the land along the Thames Estuary and River Thames over the past few decades / past century, reflecting an absolute rise in sea level of about $1 \mathrm{~mm} \mathrm{a}^{-1}$ (Bingley et al., 2007; Bingley et al., 2008).

The consequences for the methodology of geological analysis of land level change and its geological interpretation were unforeseen. The AG/GPS-aligned PSI estimates of vertical ground velocity demonstrate a new level of understanding of local structural control that was not previously attainable.

The striking correlation between the ground velocity map and subsurface/basement geology in this area masked by urban cover raises the intriguing possibility of using PSInSAR to study or tie together deep geology patterns in other similarly masked areas, including those lacking regional geophysical data.

Acknowledgements: The research described in this paper was funded by the Department for Environment, Food and Rural Affairs (Defra) and the Environment Agency (EA) in the UK. A full, formal scientific report on this research has been presented by Bingley et al. (2007). We would like to acknowledge the data and products provided by IGS, the services of the NERC British Isles continuous GNSS Facility (BIGF) and the PSMSL. The views expressed in this article are those of the authors and do not represent the views of either Defra or the EA.

Aldiss, Burke, and Chacksfield publish with the permission of the Executive Director, British Geological Survey. We thank the numerous BGS colleagues who assisted the original project work with ideas and with data, especially Doug Tragheim and Steve Booth, and Luke Bateson and Francesca Cigna, for their support with PSI matters. Burren and Press publish with the approval of NPA Satellite Mapping Ltd. Mark Haynes and Michael Riedmann, both formerly with NPA, made important contributions to the radar image processing.

We also thank the two referees for their challenging and helpful comments.

\section{References}

Adam, N., Parizzi, A., Eineder, M., Crosetto, M., 2009. Practical persistent scatterer processing validation in the course of the Terrafirma project. Journal of Applied Geophysics 69, 59-65.

Aldiss, D.T., in press. Under-representation of faults on geological maps of the London region: reasons, consequences and solutions. Proceedings of the Geologists' Association. 
Aldiss, D.T., Burke, H.F., Chacksfield, B.C., Tragheim, D.G., 2006. Absolute fixing of tide gauge benchmarks and land levels: the BGS contribution to a report on a study of the London and Thames estuary region. British Geological Survey Commissioned Report, CR/07/043 (Nottingham, UK). Available from http://nora.nerc.ac.uk/10300/.

Allen, J.R.L., 2000a. Holocene coastal lowlands in NW Europe: autocompaction and the uncertain ground. Geological Society, London, Special Publications 175, 239-252.

Allen, J.R.L., 2000b. Morphodynamics of Holocene salt marshes: a review sketch from the Atlantic and Southern North Sea coasts of Europe. Quaternary Science Reviews 19, 11551231.

Baker, T.F., Curtis, D.J., Dodson, A.H., 1995. Ocean Tide Loading and GPS. GPS World 6, 54-59.

Bateson, L.B., Barkwith, A., Hughes, A.G., Aldiss, D.T., 2009. Terrafirma: London H-3 Modelled Product. Comparison of PS data with the results of a groundwater abstraction related subsidence model. British Geological Survey Commissioned Report, OR/09/032 (Nottingham, UK). Available from http://nora.nerc.ac.uk/8581/.

Bingley, R.M., Ashkenazi, V., Penna, N.T., Booth, S.J., Ellison, R.A., Morigi, A.N., 1999. Monitoring changes in regional ground level, using high precision GPS. Environment Agency R\&D Technical Report, W210. Available from http://www.freshwaterlife.org/projects/media/projects/images/0/6683_ca_object_representati ons_media_70_original.pdf.

Bingley, R.M., Teferle, F.N., Orliac, E.J., Dodson, A.H., Williams, S.D.P., Blackman, D.L., Baker, T.F., Riedmann, M., Haynes, M., Aldiss, D.T., Burke, H.C., Chacksfield, B.C., Tragheim, D.G., 2007. Absolute fixing of tide gauge benchmarks and land levels: Measuring changes in land and sea Levels around the coast of Great Britain and along the Thames estuary and River Thames using GPS, absolute gravimetry, Persistent Scatterer Interferometry and tide gauges. Defra (Department for Environment, Food and Rural Affairs) R\&D Technical Report, FD2319/TR. Available from http://sciencesearch.defra.gov.uk/Document.aspx?Document=FD2319_5408_TRP.pdf.

Bingley, R.M., Teferle, F.N., Orliac, E.J., Dodson, A.H., Williams, S.D.P., Blackman, D.L., Baker, T.F., Riedmann, M., Haynes, M., Press, N., Aldiss, D.T., Burke, H.C., Chacksfield, B.C., Tragheim, D., Tarrant, O., Tanner, S., Reeder, T., Lavery, S., Meadowcroft, I., Surendran, S., Goudie, J.R., Richardson, D., 2008. Measurement of current changes in land levels as input to long-term planning for flood risk management along the Thames estuary. Journal of Flood Risk Management 1, 162-172.

Boyle, J., Stow, R., Wright, P., 2000. InSAR imaging of London surface movement for structural damage management and water resource conservation. Report for BNSC Link programme, Project R4/019. Available from http://citeseerx.ist.psu.edu/viewdoc/summary?doi=10.1.1.20.5030.

Bradley, S.L., Milne, G.A., Shennan, I., Edwards, R., 2011. An improved glacial isostatic adjustment model for the British Isles. Journal of Quaternary Science 26, 541-552. 
Bradley, S.L., Milne, G.A., Teferle, F.N., Bingley, R.M., Orliac, E.J., 2009. Glacial isostatic adjustment of the British Isles: new constraints from GPS measurements of crustal motion. Geophysical Journal International 178, 14-22.

Bristow, C.R., 1985. Geology of the country around Chelmsford. Memoir of the British Geological Survey Sheet 241 (England and Wales).

Burland, J.B., Standing, J.R., Jardine, F.M., 2001. Building response to tunnelling: case studies from construction of the Jubilee Line Extension, London. Thomas Telford.

Busby, J.P., Smith, N.J.P., 2001. The nature of the Variscan basement in southeast England: evidence from integrated potential field modelling. Geological Magazine 138, 669-685.

Colesanti, C., Ferretti, A., Novali, F., Prati, C., Rocca, F., 2003a. SAR monitoring of progressive and seasonal ground deformation using the permanent scatterers technique. Geoscience and Remote Sensing, IEEE Transactions on 41, 1685-1701.

Colesanti, C., Ferretti, A., Prati, C., Rocca, F., 2003b. Monitoring landslides and tectonic motions with the Permanent Scatterers Technique. Engineering Geology 68, 3-14.

Crosetto, M., Monserrat, O., Iglesias, R., Crippa, B., 2010. Persistent Scatterer Interferometry: Potential, limits and initial C-and X-band comparison. Photogrammetric engineering and remote sensing 76, 1061-1069.

D'Olier, B., 1982. Differential subsidence on the Essex coast. Proceedings of the Geologists' Association 93, 317-318.

Devoy, R.J.N., 1979. Flandrian sea level changes and vegetation history of the Lower Thames estuary. Philosophical Transactions of the Royal Society of London B285, 355-407.

Donnelly, L.J., 2009. A review of international cases of fault reactivation during mining subsidence and fluid abstraction. Quarterly Journal of Engineering Geology and Hydrogeology 42, 73-94.

Drury, S.A., 1993. Image interpretation in geology, 2nd ed. Chapman \& Hall London.

Ellison, R.A., Woods, M.A., Allen, D.J., Forster, A., Pharaoh, T.C., King, C., 2004. Geology of London. Memoir of the British Geological Survey Sheets 256 (North London), 257 (Romford), 270 (South London) and 271 (Dartford) (England and Wales).

Environment Agency, 1997. Rising groundwater levels in the Chalk-basal sands aquifer of the central London Basin.

Environment Agency, 2006. Groundwater levels in the Chalk-basal sands aquifer of the central London Basin.

Ferretti, A., Prati, C., Rocca, F., 2000. Non-uniform motion monitoring using the permanent scatterers technique, FRINGE'99: Advancing ERS SAR interferometry from applications towards operations. ESA, Liège, pp. 1-6. 
Ferretti, A., Prati, C., Rocca, F., 2001. Permanent scatterers in SAR interferometry. Geoscience and Remote Sensing, IEEE Transactions on 39, 8-20.

Ford, J.R., Mathers, S.J., Royse, K.R., Aldiss, D.T., Morgan, D.J.R., 2010. Geological 3D modelling: scientific discovery and enhanced understanding of the subsurface, with examples from the UK. Zeitschrift der Deutschen Gesellschaft für Geowissenschaften 161, 205-218.

Freeze, R.A., Cherry, J.A., 1979. Groundwater. Prentice-Hall, London.

Gehrels, W.R., 2010. Late Holocene land- and sea-level changes in the British Isles: implications for future sea-level predictions. Quaternary Science Reviews 29, 1648-1660.

Greensmith, J.T., Tucker, E.V., 1980. Evidence for differential subsidence on the Essex coast. Proceedings of the Geologists' Association 91, 169-175.

Hamilton, A., Riches, J., Realey, G., Thomas, H., 2008. 'ELDRED': new water for London from old assets. Proceedings of the Institution of Civil Engineers-Civil Engineering 161, 2634.

Heleno, S.I.N., Oliveira, L.G.S., Henriques, M.J., Falcão, A.P., Lima, J.N.P., Cooksley, G., Ferretti, A., Fonseca, A.M., Lobo-Ferreira, J.P., Fonseca, J.F.B.D., 2011. Persistent Scatterers Interferometry detects and measures ground subsidence in Lisbon. Remote Sensing of Environment 115, 2152-2167.

Horton, B.P., Shennan, I., 2009. Compaction of Holocene strata and the implications for relative sea-level change on the east coast of England. Geology 37, 1083-1086.

House, M.R., 1995. Orbital forcing timescales: an introduction. Geological Society, London, Special Publications 85, 1-18.

Jones, M.A., Hughes, A.G., Jackson, C.R., Van Wonderen, J.J., 2012. Groundwater resource modelling for public water supply management in London. Geological Society, London, Special Publications 364, 99-111.

Kelsey, J., 1972. Geodetic aspects concerning possible subsidence in southeastern England. Philosophical Transactions of the Royal Society of London. Series A, Mathematical and Physical Sciences 272, 141-149.

Lee, M.K., Pharaoh, T.C., Williamson, J.P., Green, C.A., De Vos, W., 1993. Evidence on the deep structure of the Anglo-Brabant Massif from gravity and magnetic data. Geological Magazine 130, 575-582.

Mair, R.J., Taylor, R.N., Bracegirdle, A., 1993. Subsurface settlement profiles above tunnels in clays. Geotechnique 43, 315-320.

Mortimore, R.N., Newman, T.G., Royse, K., Scholes, H., Lawrence, U., 2011. Chalk: its stratigraphy, structure and engineering geology in east London and the Thames Gateway. Quarterly Journal of Engineering Geology and Hydrogeology 44, 419-444.

Muir Wood, R., 1990. London: not waving but drowning. Terra Nova 2, 284-291. 
Paul, M.A., Barras, B.F., 1998. A geotechnical correction for post-depositional sediment compression: examples from the Forth valley, Scotland. Journal of Quaternary Science 13, 171-176.

Peltier, W.R., Shennan, I., Drummond, R., Horton, B., 2002. On the postglacial isostatic adjustment of the British Isles and the shallow viscoelastic structure of the Earth. Geophysical Journal International 148, 443-475.

Riedmann, M., Haynes, M., 2007. Developments in synthetic aperture radar interferometry for monitoring geohazards, In: Teeuw, R.M. (Ed.), Mapping hazardous terrain using remote sensing. Special Publication Geological Society, London 283, pp. 45-51.

Shennan, I., 1989. Holocene crustal movements and sea-level changes in Great Britain. Journal of Quaternary Science 4, 77-89.

Shennan, I., Bradley, S., Milne, G., Brooks, A., Bassett, S., Hamilton, S., 2006. Relative sealevel changes, glacial isostatic modelling and ice-sheet reconstructions from the British Isles since the Last Glacial Maximum. Journal of Quaternary Science 21, 585-599.

Shennan, I., Horton, B., 2002. Holocene land- and sea-level changes in Great Britain. Journal of Quaternary Science 17, 511-526.

Standing, J., Burland, J., 2006. Unexpected tunnelling volume losses in the Westminster area, London. Geotechnique 56, 11-26.

Sumbler, M.G., 1996. British regional geology: London and the Thames Valley, Fourth ed. HMSO for the British Geological Survey, London.

Teeuw, R.M., 2007. Applications of remote sensing for geohazard mapping in coastal and riverine environments, In: Teeuw, R.M. (Ed.), Mapping hazardous terrain using remote sensing. Special Publications of the Geological Society, London 283, pp. 93-106.

Teferle, F.N., Bingley, R.M., Orliac, E.J., Williams, S.D.P., Woodworth, P.L., McLaughlin, D., Baker, T.F., Shennan, I., Milne, G.A., Bradley, S.L., Hansen, D.N., 2009. Crustal motions in Great Britain: evidence from continuous GPS, absolute gravity and Holocene sea level data. Geophysical Journal International 178, 23-46.

Tomas, R., Herrera, G., Cooksley, G., Mulas, J., 2011. Persistent Scatterer Interferometry subsidence data exploitation using spatial tools: The Vega Media of the Segura River Basin case study. Journal of Hydrology 400, 411-428.

Tosi, L., Teatini, P., Carbognin, L., Brancolini, G., 2009. Using high resolution data to reveal depth-dependent mechanisms that drive land subsidence: The Venice coast, Italy. Tectonophysics 474, 271-284.

Wahr, J., 1995. Earth Tides, Global Earth Physics, A Handbook of Physical Constants, pp. 40-46. 
Williams, S.D., Baker, T.F., Jeffries, G., 2001. Absolute gravity measurements at UK tide gauges. Geophysical Research Letters 28, 2317-2320.

Woods, E., 2004. Bored tunnels. ARUP Journal 39, 22-28.

Wooldridge, S.W., 1923. The minor structures of the London Basin. Proceedings of the Geologists' Association 34, 175-193, IN171.

Wooldridge, S.W., Linton, D.L., 1955. Structure, surface and drainage in south-east England. George Philip and Son, London. 
Table 1: Summary statistics for PS points within each domain

\begin{tabular}{|c|c|c|c|c|c|c|}
\hline \multirow[t]{2}{*}{ Domain } & \multirow{2}{*}{$\begin{array}{l}\text { Number of } \\
\text { PS points }\end{array}$} & \multicolumn{5}{|c|}{ Vertical ground velocity in $\mathrm{mm} \mathrm{a}^{-1}$} \\
\hline & & Average & Minimum & Maximum & Variance & $\begin{array}{l}\text { Standard } \\
\text { Deviation }\end{array}$ \\
\hline 1 & 23632 & 0.34 & -7.51 & 9.16 & 0.68 & 0.83 \\
\hline $2 \mathrm{~A}$ & 66802 & -0 11 & -1051 & 611 & 068 & 027 \\
\hline $2 B$ & 79863 & -0.34 & -10.67 & 10.91 & 0.74 & 0.86 \\
\hline $3 A$ & 10304 & -0.55 & -9.06 & 4.78 & 0.68 & 0.83 \\
\hline $3 B$ & 59741 & -0.61 & -12.96 & 6.44 & 0.65 & 0.80 \\
\hline $3 C$ & 81264 & -0.68 & -12.89 & 11.89 & 0.64 & 0.80 \\
\hline 3D & 18893 & -0.53 & -12.24 & 10.34 & 0.66 & 0.81 \\
\hline $3 \mathrm{E}$ & 27166 & -0.59 & -11.75 & 9.74 & 0.74 & 0.86 \\
\hline & & & & & & \\
\hline $4 \mathrm{~A}$ & 36318 & -1.02 & -11.89 & 6.53 & 0.67 & 0.82 \\
\hline $4 \mathrm{~B}, 4 \mathrm{~F}, 4 \mathrm{H}$ & 163667 & -0.86 & -15.02 & 11.37 & 0.71 & 0.84 \\
\hline 4C & 171691 & -1.06 & -13.78 & 9.74 & 0.66 & 0.81 \\
\hline $4 \mathrm{D}$ & 26180 & -0.98 & -14.80 & 8.47 & 0.71 & 0.84 \\
\hline $4 \mathrm{E}$ & 52884 & -0.86 & -15.35 & 10.37 & 0.77 & 0.88 \\
\hline $4 G$ & 2963 & -1.04 & -12.74 & 3.31 & 0.81 & 0.90 \\
\hline $5 \mathrm{~A}$ & 31955 & -1.55 & -16.68 & 8.63 & 0.69 & 0.83 \\
\hline $5 B$ & 6271 & -1.18 & -6.45 & 3.85 & 0.71 & 0.84 \\
\hline $5 \mathrm{C}$ & 5441 & -1.31 & -10.75 & 3.35 & 1.15 & 1.07 \\
\hline $5 \mathrm{D}$ & 34844 & -1.49 & -20.59 & 4.52 & 0.83 & 0.91 \\
\hline $5 \mathrm{E}$ & 28991 & -1.23 & -10.34 & 8.61 & 0.69 & 0.83 \\
\hline $5 F$ & 3398 & -1.30 & -5.59 & 5.27 & 0.91 & 0.95 \\
\hline $6 \mathrm{~A}$ & 1066 & -2.06 & -6.93 & 2.50 & 1.79 & 1.34 \\
\hline $6 B$ & 272 & -2.43 & -5.10 & -0.22 & 0.76 & 0.87 \\
\hline $6 \mathrm{C}$ & 655 & -2.25 & -9.33 & 1.27 & 2.44 & 1.56 \\
\hline $6 \mathrm{D}$ & 14090 & -1.99 & -22.34 & 6.58 & 3.49 & 1.87 \\
\hline $6 \mathrm{E}$ & 3322 & -2.05 & -15.23 & 4.34 & 2.68 & 1.64 \\
\hline
\end{tabular}

Note the uniform values for variance and standard deviation in Domains 1 to 5 , in particular. 


\section{London land levels: Figures with captions}

Figure 1: Location of study area with bedrock geology
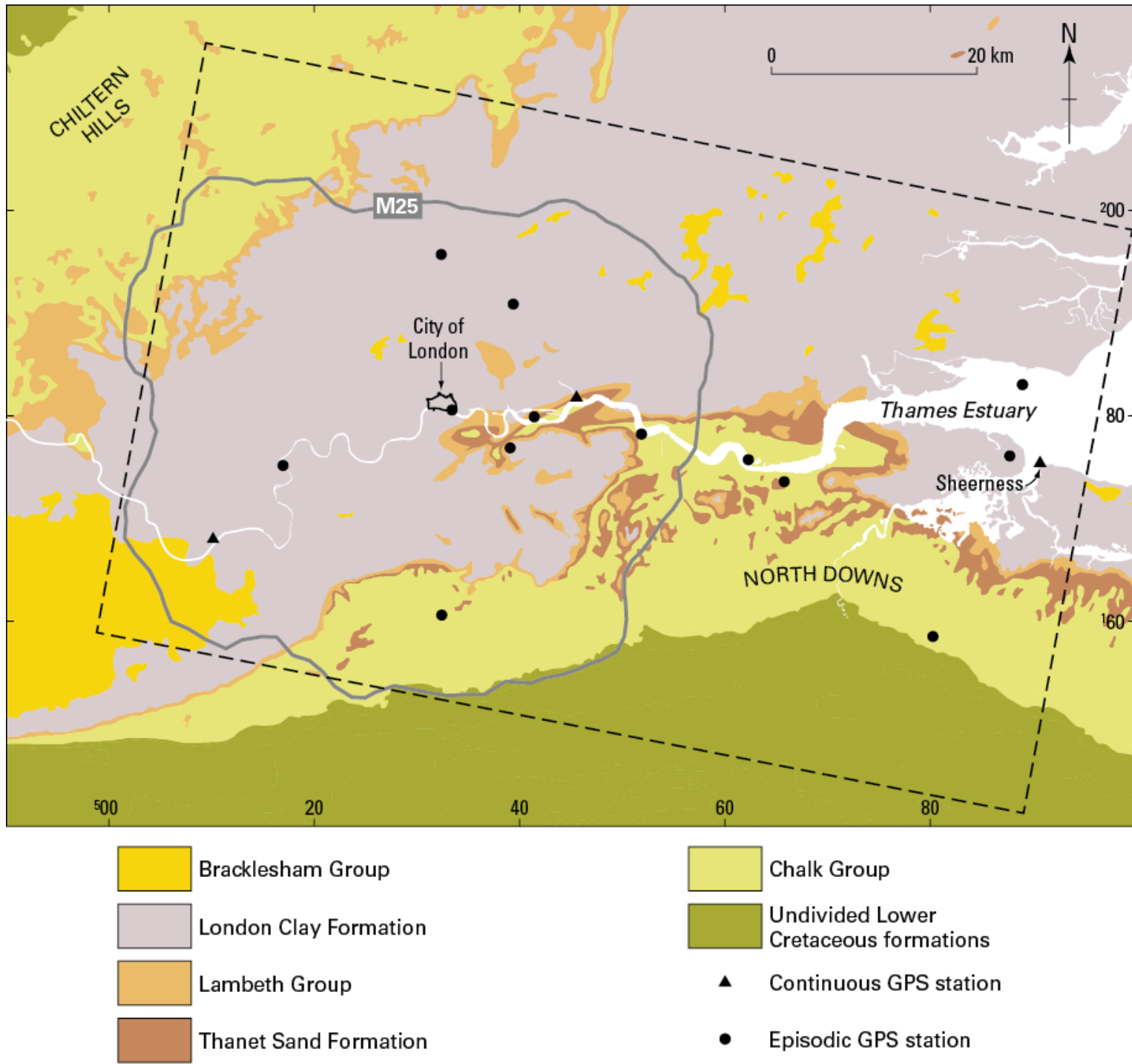

- Continuous GPS station

- Episodic GPS station

OS OpenData: Contains Ordnance Survey data @ Crown copyright and database rights 2010.

Position of modern London is indicated by the ancient City of London and by the M25 orbital motorway. Dashed line marks the extent of the Permanent Scatterer Interferometry (PSI) data. For details of the GPS stations, see Bingley et al. (2007, 2008). 
Figure 2: Generalised vertical ground velocity domains, gravity field and basement terranes

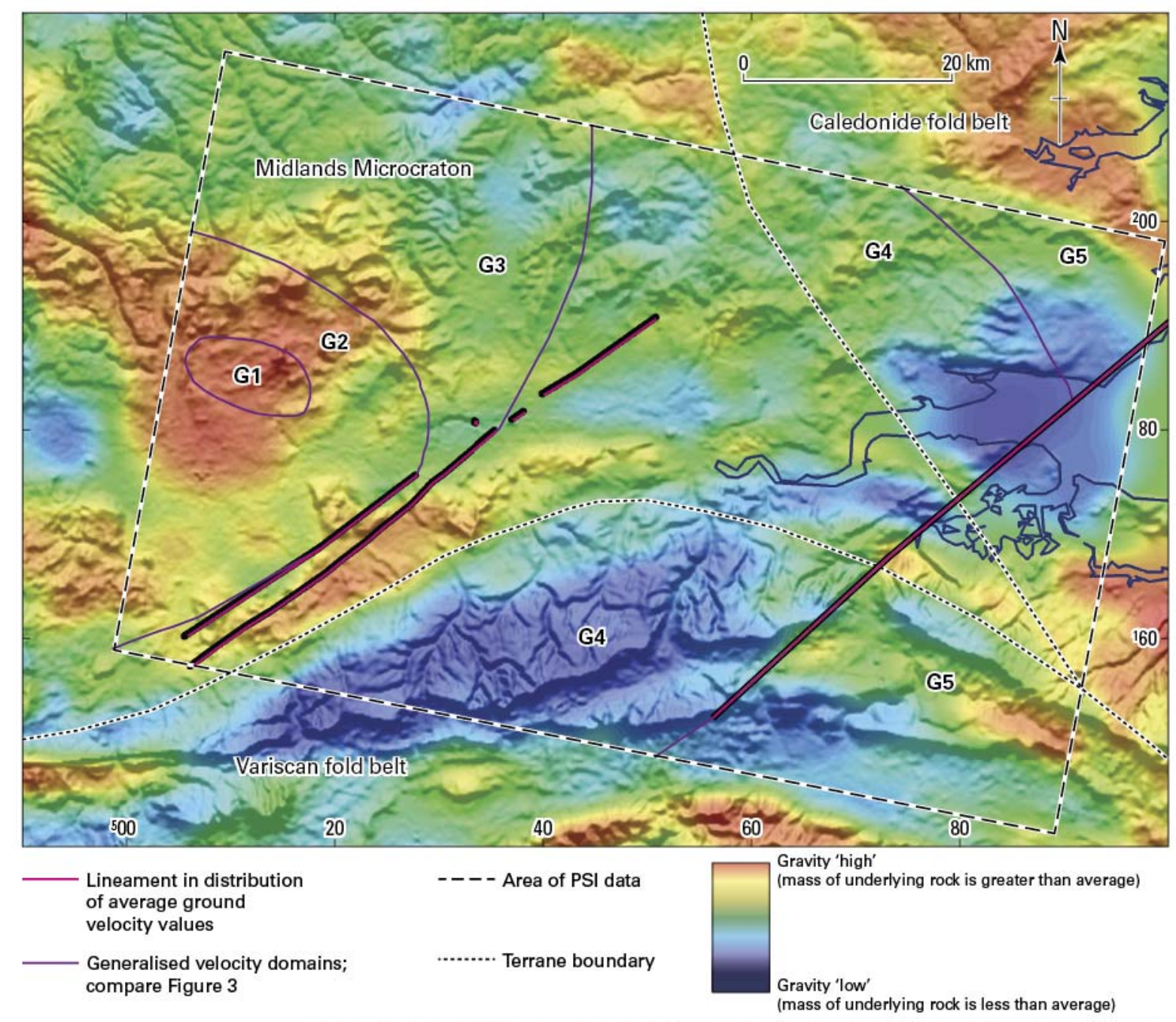

DTM using NextMap Britain ${ }^{\mathrm{M} M}$ dataset covering England, Wales and Scotland. NextMap Britain ${ }^{\mathrm{TM}}$ elevation data from Intermap Technologies.

Bouguer gravity field stripped to base of Mesozoic succession (Aldiss et al., 2006) and draped on shaded relief digital terrain model. Range of values in gravity data is from approximately 0 to $-30 \mathrm{mGal}$. G1 to G5 are generalised regional vertical ground velocity domains referred to in Section 6.3. 
Figure 3A: Point plot of land level change determinations from Persistent Scatterer Interferometry (PSI) data

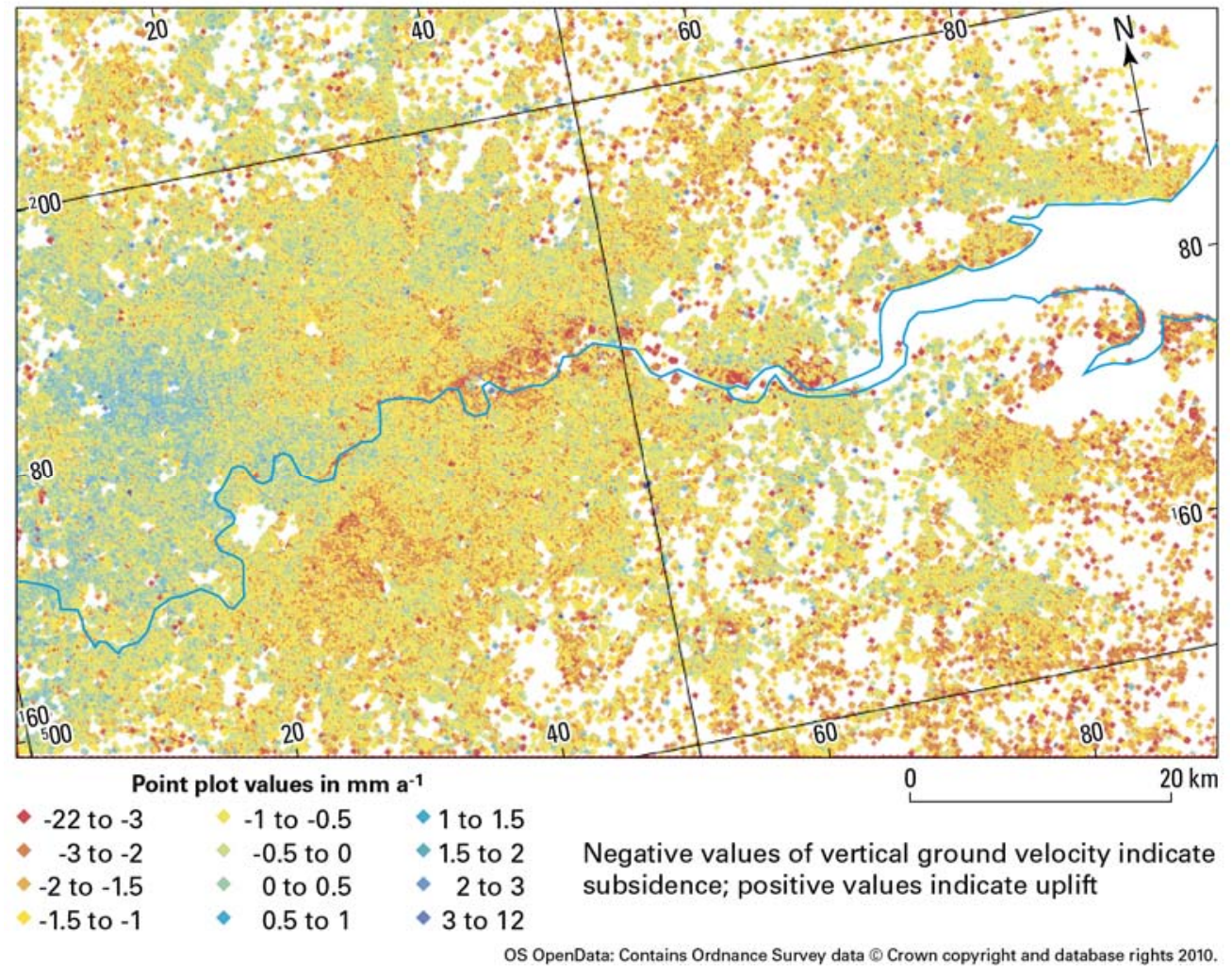

Figure 3B: Point plot of land level change determinations with domain boundaries and lineaments

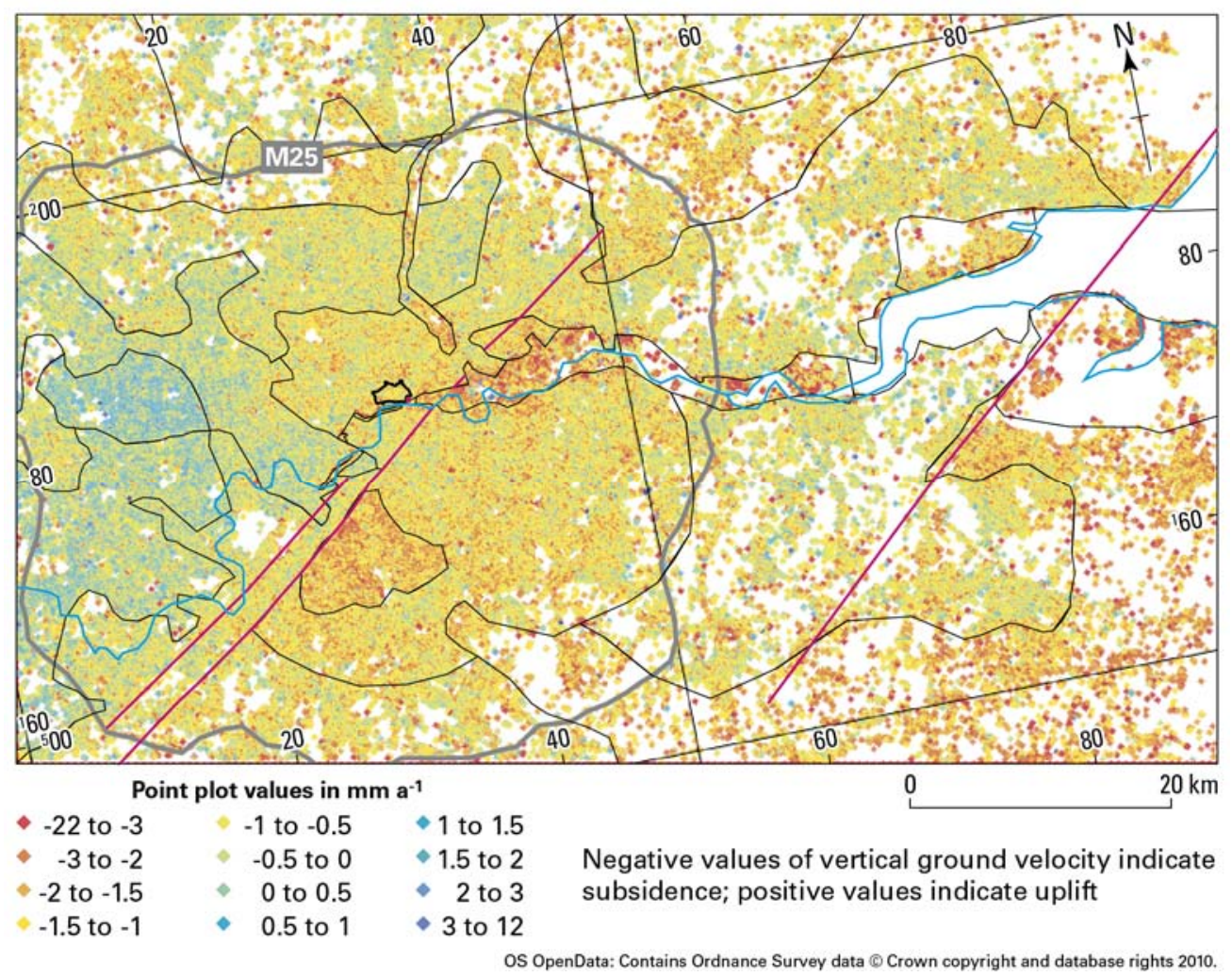


Figure 4: Average vertical ground velocity domains

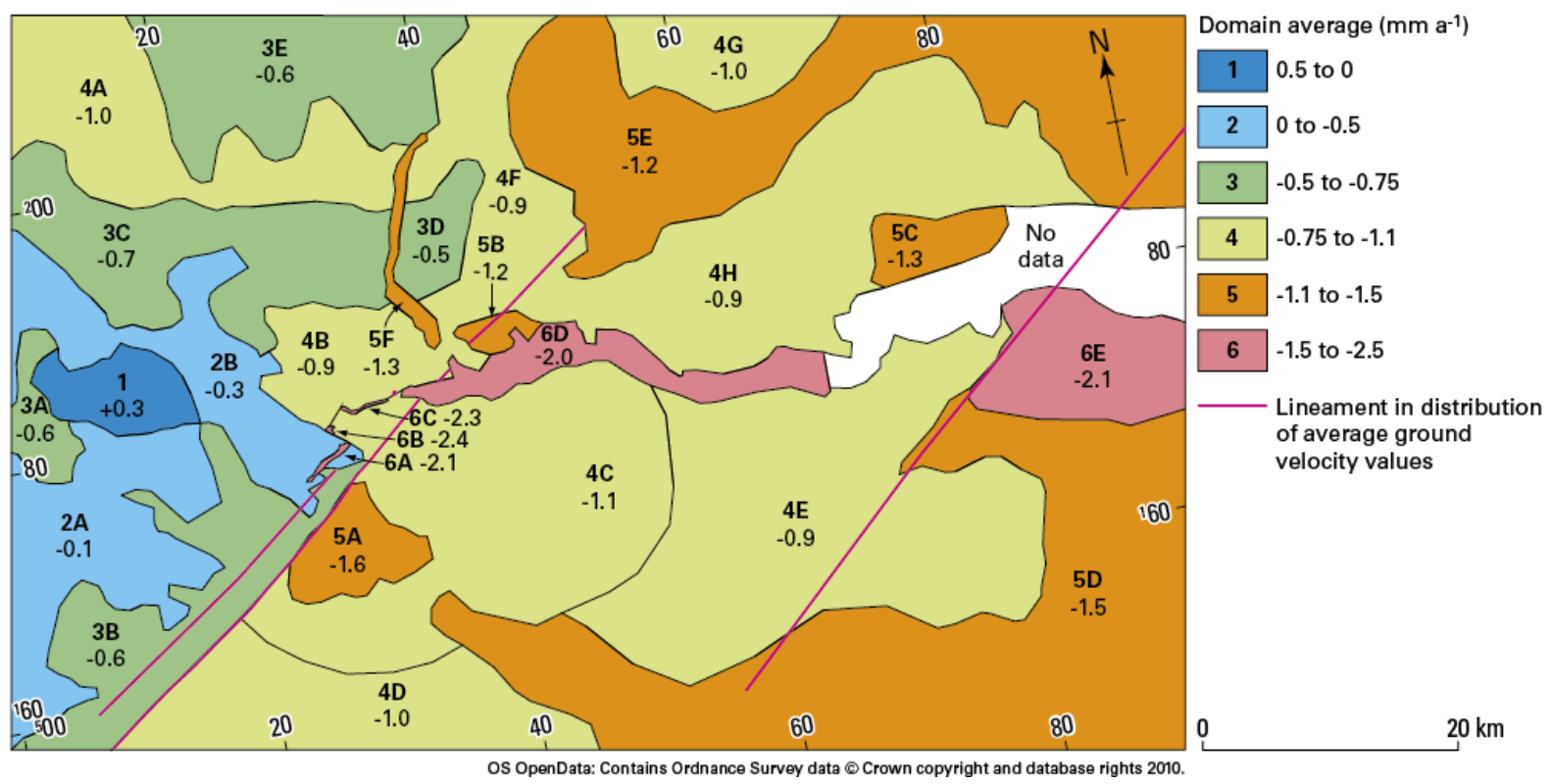

Domain labels indicate rank of average vertical ground velocity with a letter to identify each domain. Each label is accompanied by the average value of vertical ground velocity for that domain. Compare with Figure 3 and Table 1. 
Figure 5: Lineaments, faults and Holocene deposits

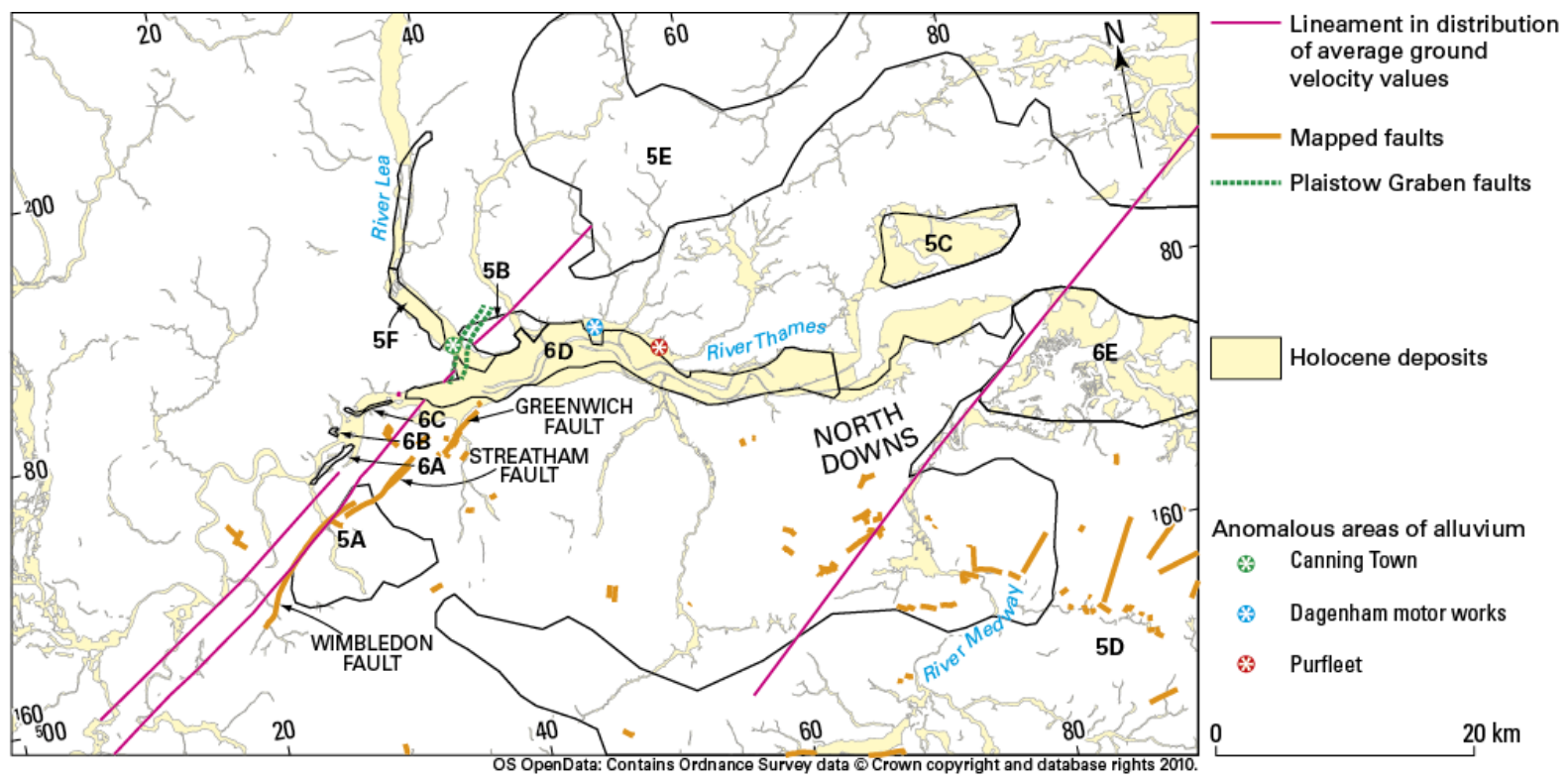

Position of Plaistow Graben taken from Mortimore et al. (2011).

Geological map information taken from British Geological Survey DiGMapGB-50

(Copyright NERC). 
Figure 6: Path of the River Thames around Domain 1

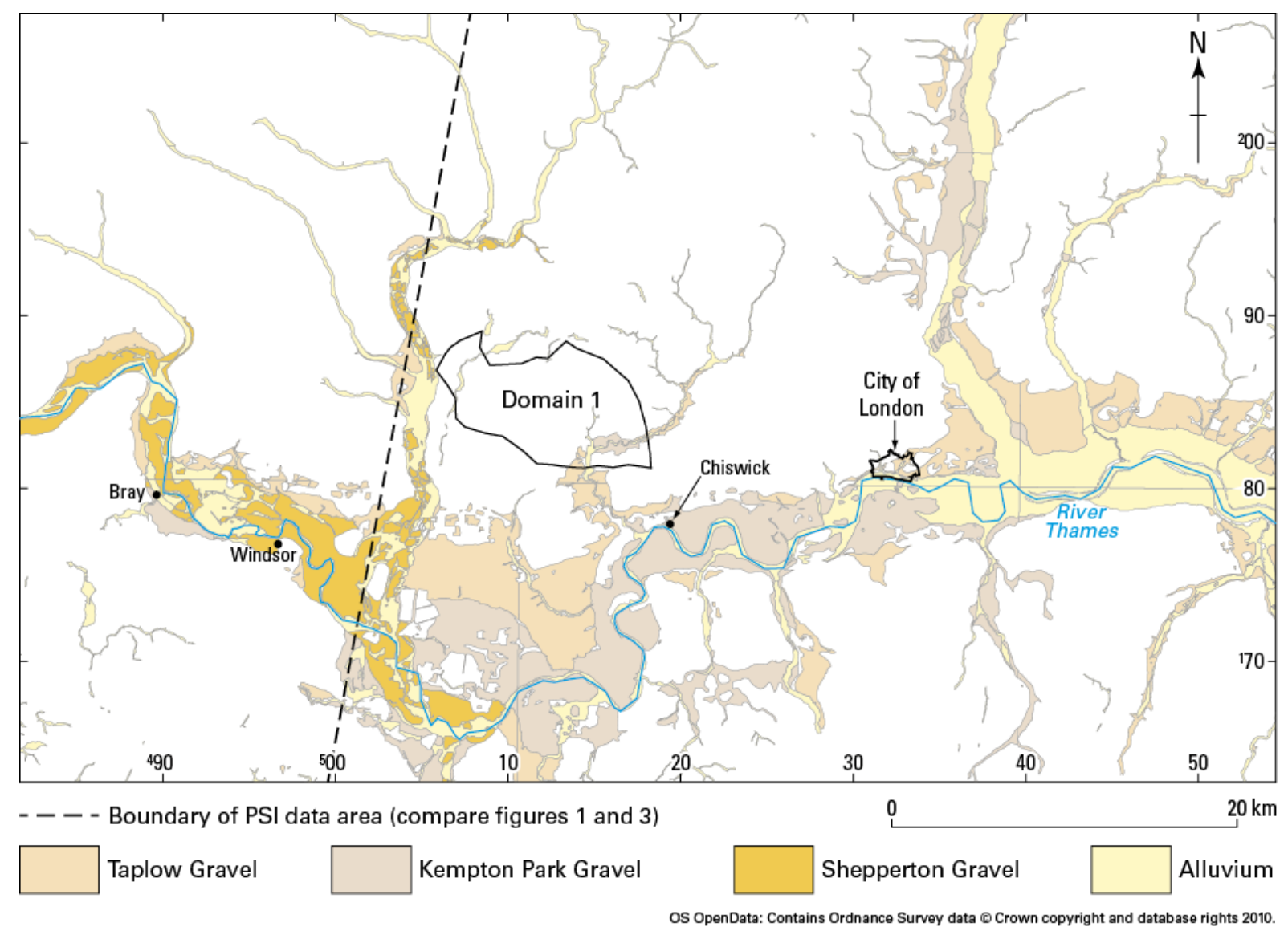

Domain 1 is as in Figure 4; the adjacent section of the River Thames has apparently been deflected southwards between Windsor and Chiswick. Note that the area of apparent local uplift represented by Domain 1 may have varied through time. City of London as in Figure 1. Geological map information taken from British Geological Survey DiGMapGB-50 (Copyright NERC). 
Figure 7: Change in groundwater level compared with vertical ground velocity domains

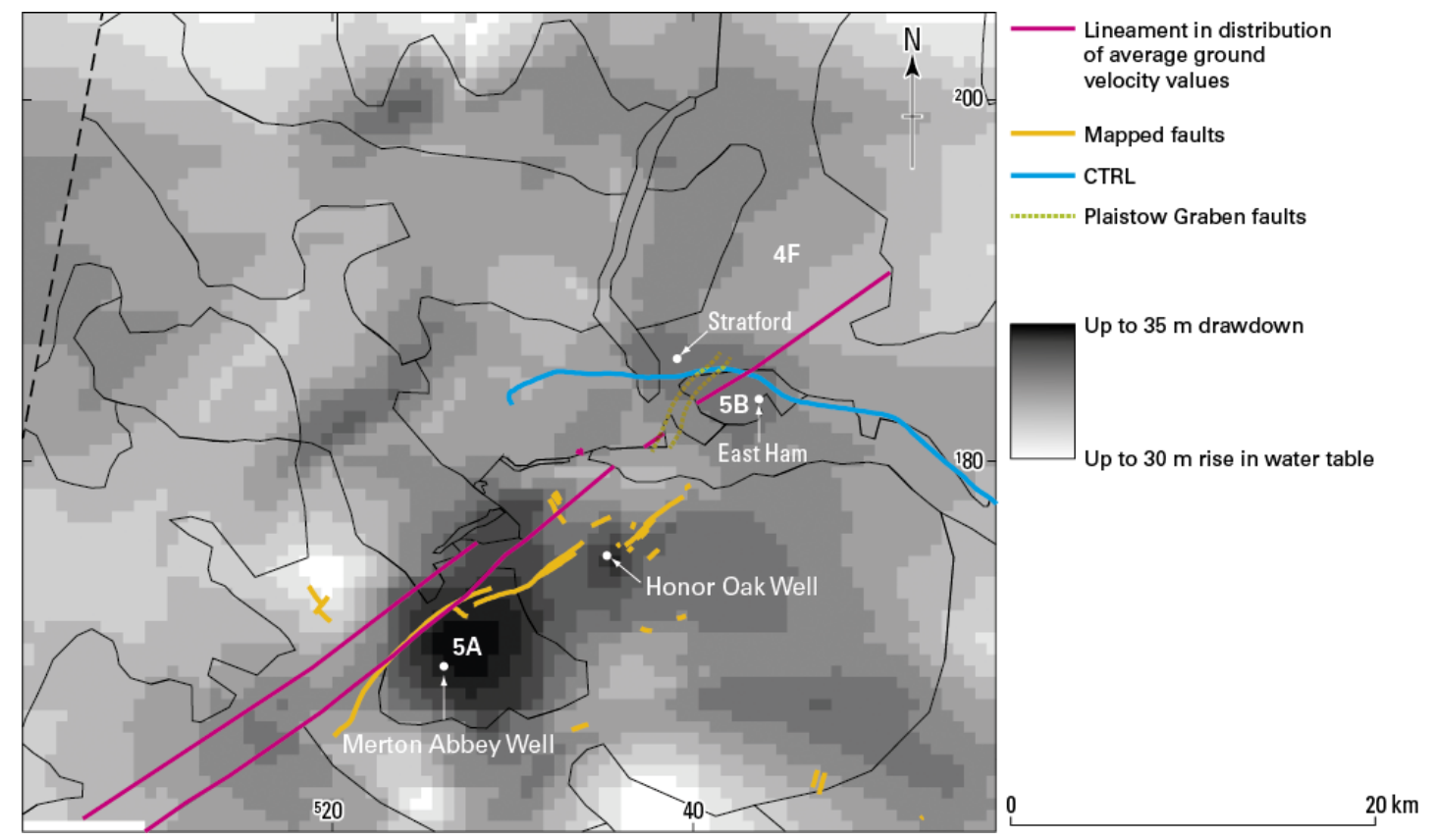

Change in groundwater level from January 1997 to January 2006, compared with vertical ground velocity during March 1997 to December 2005. Position of two major public water supply wells indicated. Domains and lineaments as Figures 4 and 6. CTRL is the Channel Tunnel Rail Link (latterly known as 'High Speed 1'), which terminates in north central London. 